\title{
INNOVATION PERFORMANCE OF THE CZECH REGIONS
}

\section{Vladimír Žítek}

Masaryk University, Faculty of Economics and Administration, Lipová 41a, 60200 Brno, Czech Republic, e-mail: zitek@econ.muni.cz, phone: +420549494627

\begin{abstract}
Innovations play the key role in the today's globalized world economy. This is a fact which also the European Union is aware of. Therefore, it is concerned with the innovation support. And individual national economies focus on the characteristics that influence their innovation potential. Several various methods are used for the evaluation of the innovation efficiency, for example the Summary Innovation Index (SII), by the means of which the individual countries are assessed through 25 indicators. This contribution aims to find out which of the indicators involved in the method are available, so that this method could be used for the evaluation of the innovation efficiency of the individual regions at the level of NUTS3. For this purpose, the Regional Innovation Index (RII) has been defined and it uses 16 indicators, the same as or similar to the original methodology, to compare the regions of the Czech Republic. RII maintains the original weight ratio of innovation input and output dimensions. RII is used as a base for the creation of regional typology, which divides the regions into those considerably above average, those above average, the average ones, those below average and those considerably below average. Moreover, the results are compared with the conclusions of another study, which used a simpler methodology. This makes us able to draw final conclusions and also to define bases for further research.
\end{abstract}

Key words: Regional development, Innovation index, evaluation, typology of regions

JEL Classification: R120, O180

DOI: $10.2478 / \mathrm{v} 10135-011-0003-1$ 


\section{INNOVATION PERFORMANCE OF CZECH REGIONS ${ }^{1}$}

\section{Vladimír Žítek ${ }^{2}$}

\section{Introduction}

After the access to EU, Czech firms have had to (as well as enterprises in all new member states) compete on single European market which is characterized by high freedom and thus by more severe competition. Furthermore, in existing global world the enterprises have faced competition from other countries. Until then Czech firms had been able to successfully derive benefit from their competitive advantages, for example low cost (especially labour cost) and knowledge of local contacts. But low-cost strategy is not sustainable in future because of competition from big countries with cheap labour force (for example China or India). On this account, it is necessary to use competition advantages, such as innovation ability of enterprises, qualification and mobility of human resources or research and technology. Just innovations are considered as the driving force of economic and social regional development and they participate in employment growth, economic growth and international competitiveness.

In the recent years, there have been tendencies to direct the innovation support from the national level towards the regional level, as it shows that many successful initiatives started at regional levels. It means that the significance of the place for the innovation development has been acknowledged. Regions have some specific features that do not appear on the national level. It is vital for the innovation development that companies, research and universities are close to each other. This closeness results in a flow of knowledge with all its positive effects (e.g. accumulation of useful knowledge, qualified university graduates or networking). Geographic closeness makes sharing of tacit knowledge possible and increases the capacity for localized learning. Tacit knowledge is the knowledge that cannot be written down and classified and it is learnt by experience. Localized learning is also possible thanks to the common base of regional institutions.

Innovation policies and measures of national states and regions are also dependent on the availability of statistical data on innovations. Generally spoken, it is possible to assess the innovation efficiency and innovation environment using two basic indicator types: individual indicators and summary indicators. The individual indicators of innovations are found out using statistical surveys. It is important that statistics of individual states are comparable. Therefore, a unified methodology for the collection of data on innovations has been created and it is called Oslo Manual. The Oslo Manual was created at the beginning of the 1990s by the European Commission, Eurostat and OECD. The Oslo Manual is the basis for surveys on innovations carried out in

\footnotetext{
${ }^{1}$ The contribution was made thanks to the project 1M0524 Research Centre for Competitiveness of Czech Economy

${ }^{2}$ Masaryk University, Faculty of Economics and Administration, Lipová 41a, 60200 Brno, Czech Republic
} 
individual countries - Community Innovation Surveys (CIS). Since 2004 the statistics on innovations in the EU has also had its legal foundation - Commission Regulation (EC) No. 1450/2004 of 13 August 2004, implementing Decision No. 1608/2003/EC of the European Parliament and of the Council, concerning the production and development of Community statistics on innovation.

An example of a summary indicator assessing the innovation efficiency using the synthesis of individual criteria is the assessment called European Innovation Scoreboard. The European Innovation Scoreboard (EIS) summarizes the basic elements of innovation performance and it is annually published by Directorate-General Enterprise of European Commission as the part of program "Trend Chart on Innovation in Europe." The EIS 2007 evaluates all 27 countries of the EU and 10 other countries (Croatia, Turkey, Iceland, Norway, Switzerland, Japan, the US, Australia, Canada and Israel). EIS 2007 contains 25 indicators divided into 2 main topics (innovation inputs and innovation outputs) and 5 categories (Innovation drivers, Knowledge creation, Innovation \& Entrepreneurship, Applications, Intellectual Property). On the basis of these indicators one Summary Innovation Index (SII) and five Composite Indices are compiled for each country. The value of Summary Innovation Index can be from 0 to 1 - the higher, the better. In addition to absolute Summary Innovation Index, the trend of SII (average change for certain period) is monitored, too.

\section{Objectives and Methodology}

The aim of this article is to use SII to assess the innovation efficiency of regions. For this purpose it is possible to create the Regional Innovation Index (RII). When constructing it, certain limitations related to the availability of the data included in SII are to be expected. Some data is only monitored at the level of national economies (NUTS0), other at the regional level is only obtainable from censuses (2001 and 2011 in the CR). Therefore, some corrections of specific indicators, or their replacement with other alternatives, are necessary.

On the basis of RII definition it is possible to apply the included indicators to $\mathrm{CR}$ regions (NUTS3) and by summarizing the indicators (using weight of importance 1 for input dimension and weight 2 for output dimension so that the ratio between input and output is maintained, as in the case of SII) to create the typology of CR regions and in this way to classify the regions as over average, average and below average. Individual indicators are primarily related to 2005 , which is the year when the most recent data is available. If this is not possible, the article draws attention to this fact and offers a sufficient explanation. For the purpose of the group classification, the individual indicators are recalculated as a percentage of the average, then added up and then the average is calculated. The same interval limits are used for individual groups and for the Regional Innovation Index. The interval is based on the interval for average regions, which is $90-110 \%$. The regions ranging between $110-130 \%$ are considered above average, the regions over $130 \%$ are considerably above average, $90-70 \%$ is for regions below average and below $70 \%$ are regions considerably below average.

The results can be compared with the results of the study which was carried out in 2006 and whose objective was to create a similar CR regional typology ${ }^{1}$. The foundations of

1 Žítek, Kunc, Tonev (2006) 
this typology were selected indicators of competitiveness (regional GDP, unemployment, average income, educational attainment and internal migration), which were allotted different weights of importance depending on the subjective consideration of the authors. The aim of such a comparison would be to conclude whether it is possible to reach the same results when completely different methodological approach is used, or whether the results will vary substantially.

Both the primary and the comparative study include indicators for the regions of the CR. Only the Central Bohemian region and the capital city of Prague were merged for the purposes of both the studies. This procedure leads to a partial elimination of extreme values occurring in Prague (upwards) and in the Central Bohemian region (downwards) and also to the result that the data is more realistic, as Prague is a natural centre of the Central Bohemian region and, vice versa, the region is a natural base for the capital.

\section{Indicators of innovation performance}

\section{Group 1: Innovation Drivers (input dimension)}

Summary innovation index assesses the following five indicators in this group:

- S\&E graduates per 1000 population aged 20-29,

- population with tertiary education per 100 population aged 25-64,

- broadband penetration rate (number of broadband lines per 100 population),

- $\quad$ participation in life-long learning per 100 population aged 25-64,

- $\quad$ youth education attainment level (\% of population aged 20-24 having completed at least upper secondary education).

4 indicators that are the same as or very similar to SII were chosen for the construction of the regional innovation index. Most data is based on regular or one-time selective surveys of the Czech Statistical Office. Despite great effort, we were not able to replace the indicator of educational attainment related to age, as it is not monitored at regional level. Finally, the following indicators were included in the Innovation Drivers group:

- $\quad$ the number of graduates from innovation-oriented university fields per 1000 population aged $20-29$,

- the number of population with tertiary education per 100 population aged over 25 ,

- broadband penetration rate (proportion of broadband lines per 100 households),

- the number of participants in informal education during the last 4 weeks per 100 population aged over 15 .

\section{The number of graduates from innovation-oriented university fields}

This indicator is based on a unique analysis carried out by Tonev (2007), which focuses on innovation-oriented university fields of study. Thanks to this, it is possible to process the indicators of the number of graduates from these fields in 2005. The data is related to 1000 population aged 20-29. The source for this data is a Czech Statistical Office publication called Labour Market in the CR 2003-2006. 
Naturally, the highest values are achieved in the regions with large universities; thanks to the city of Brno, the South Moravian region has an exceptional position here (20.8 graduates per 1000 population) and it is followed by Prague + the Central Bohemian region (11.9) and the Plzen region (11.6). There are no graduates in the Karlovy Vary region and the Vysočina region (the universities and colleges in these regions do not contain any innovation-oriented fields of study). The indicator for the Ustí nad Labem region and the South Bohemian region is of a very low value (both 1.3).

\section{The number of population with tertiary education}

This indicator is quite the same as the one used in SII, only with the difference that it is not possible to use the upper limit for the age interval. The source of the data is the above-mentioned publication Labour Market in the CR 2003-2006.

The highest number of population with tertiary education per 100 inhabitants is in Prague + the Central Bohemian region (18.0); the only other region above the CR region is the South Moravian region (14.9). Seven regions fall between 10.0 and 11.8. The lowest proportion of population with tertiary education is in the Liberec region (9.2), the Karlovy Vary region (8.3) and mainly in the Ústí nad Labem region (7.1 only).

\section{Broadband penetration rate}

Broadband penetration rate is a significant component of the assessment of Innovation Drivers. The indicator is based on the Czech Statistical Office survey, whose result is a study called Use of Information and Communication Technologies in Households and by Individuals in 2007. Here, we can find several indicators divided into regions. We could use the Internet Access indicator available for 2005 as well, or the Broadband Penetration Rate indicator available for 2007 only. Although there is a time disharmony, we assumed that it is more important for innovation assessment to place the material side before time and use the broadband penetration rate. The indicator at regional level in the CR is monitored at the level of households, which makes it different from SII which monitors it per population.

The highest proportion of broadband lines can be found in Prague + the Central Bohemian region (20.6 lines per 100 households), the South Moravian region (18.6) and the Hradec Králové region (17.6). On the other hand, the lowest number of lines is in the Zlín region (10.1), the Ústí nad Labem region (9.2) and the South Bohemian region (8.8).

\section{The number of participants in informal education}

When looking for an indicator which could be a suitable alternative of participation in life-long learning indicator in SII, we found out that the number of participants in informal education is the only option available in regional statistics. Informal education best corresponds with the definition of life-long learning. The used data are based on a one-time survey of the Czech Statistical Office (Results of Ad Hoc Module 2003 on Life-long Learning of 2003). The indicator is then defined, in correspondence with the source data, as a number of participants in informal education during the last 4 weeks per 100 population aged over 15 . 
The highest values are achieved by Prague + the Central Bohemian region (4.8 participants in informal education per 100 population aged over 15), the Hradec Králové region (4.5), the Plzeň region and the Ústí nad Labem region (4.3 each). The lowest values are to be found in the Karlovy Vary region and the Liberec region (3.3 each), the Olomouc region (3.2) and the South Bohemian region (3.1).

Picture 1: RII - Innovation Drivers (input dimension)

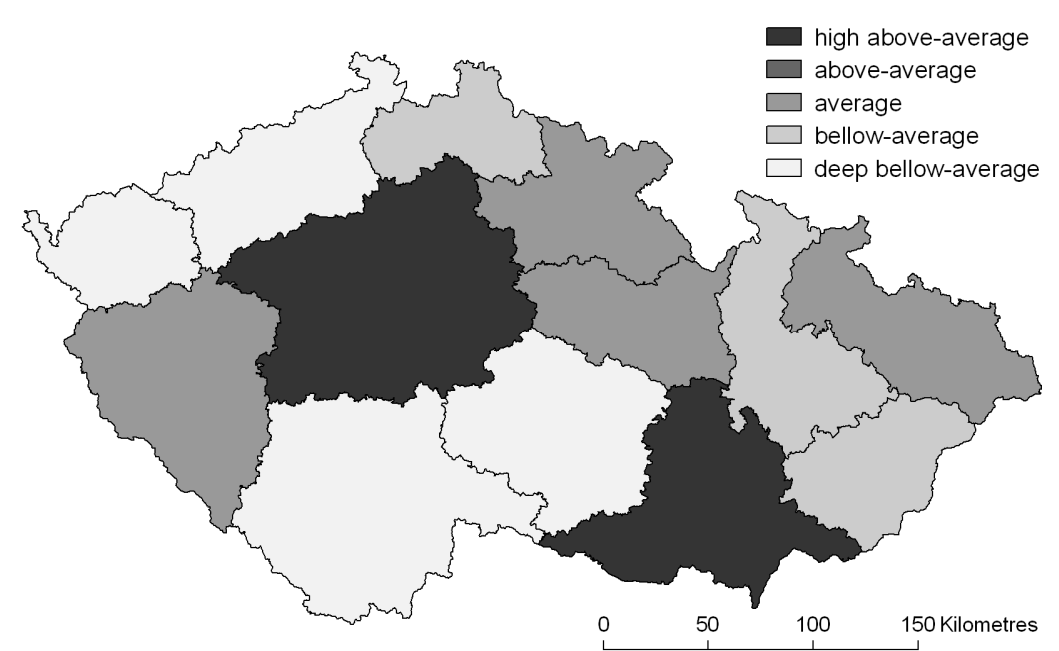

Source: author (data: Czech statistical office)

\section{Group 2: Knowledge Creation (input dimension)}

Summary innovation index assesses the following four indicators in this group:

- $\quad$ public R\&D expenditures (\% of GDP),

- business R\&D expenditures (\% of GDP),

- $\quad$ share of medium-high-tech and high-tech R\&D (\% of manufacturing R\&D expenditures),

- share of enterprises receiving public funding for innovation.

Similarly to SII, 4 indicators were chosen for the construction of the regional innovation index. There is quite a high rate of material agreement as the R\&D field is regularly monitored. The data are available for every year mainly because all entities in the CR dealing with $R \& D$ have the duty to fill in an appropriate statistical form regularly. In spite of this, some indicators had to be either slightly modified or partially replaced. The Knowledge Creation group includes the following indicators:

- $\quad$ public R\&D expenditures (\% of GDP),

- business R\&D expenditures (\% of GDP),

- $\quad$ share of high-tech R\&D (\% of business R\&D expenditures),

- the amount of grants provided from the Innovation Program per 1000 SMEs (over 20 employees). 


\section{Public R\&D expenditures}

Public R\&D expenditures, which are calculated as a sum of government and university expenditures are the basis for the creation of this indicator. The data are obtained from a Czech Statistical Office source Research and Development Indicators of 2006, where data of 2005 are available. Then, the regional GDP in common prices based on Regional Accounts 2005 is used for recalculation.

Public research is characteristic for the high degree of polarization in favour of the capital city of Prague and the second largest Czech city Brno which is located the centre of the South Moravian region. Prague + the Central Bohemian region and the South Moravian region reach values that are considerably over the average of the CR $(0.91$ and $0.78 \%$ of regional GDP respectively). All other regions are below average. Completely negligible values are achieved in the Zlín region $(0.07 \%)$, the Ústí nad Labem region $(0.03 \%)$, the Vysočina region and the Karlovy Vary region $(0.01 \%$ each).

\section{Business R\&D expenditures}

The indicator is created in the same way as the previous one, only the government $R \& D$ expenditures are replaced with business expenditures. The data come from the same sources.

The polarization of business research is not as significant as is the case of public research. Moreover, the comparison of both indicators shows that there is practically no relation between the public and the business R\&D expenditures. The highest proportion of business R\&D expenditures is in Prague + the Central Bohemian region $(1.45 \%$ of regional GDP), followed by the Pardubice region (1.19\%) and the Zlín region (1.07 \%). The least means is invested in R\&D enterprises in the Hradec Králové region $(0.39 \%)$, the Ústí nad Labem region $(0.27 \%)$ and the Karlovy Vary region $(0.10 \%)$.

\section{Share of high-tech R\&D (\% of business R\&D expenditures)}

Although this indicator very resembles the concept of SII, it was necessary to make two considerable changes for its construction because of the possibilities the Czech statistical services offer. In the Czech Republic, R\&D expenditures are only monitored in high-tech fields (CSO: High-tech sector). Business expenditures are used as the ratio indicator because manufacturing expenditures are not monitored regularly. The data are obtained from the above-mentioned source Research and Development Indicators of 2006.

The highest share of high-tech R\&D expenditures is reached in four regions which substantially differ from the other regions. These are the Plzeň region $(49.61 \%$ of business expenditures), the Pardubice region (46.35\%), the South Moravian region $(44.71 \%)$ and Prague + the Central Bohemian region $(43.38 \%)$. To the least extent high-tech R\&D shares in business research in the Vysočina region (13.58 \%), the South Bohemian region (6.91\%) and the Karlovy Vary region $(1.24 \%)$. 


\section{The amount of grants provided from the Innovation Program}

The last of the indicators for this group assesses the regions as to their success in winning public grants for innovation support. For this purpose, the CR started the Innovation Program, from which it was possible to obtain funds in the previous EU budget period, 2004-2006 for the CR. Logically, it seems to be more convenient to make calculations using the amount of grants provided than the number of companies obtaining them even though this data is also available in the Czechinvest database: The Statistics of Grant and Advantageous Loan Obtaining from OPIE programs 2004-2006. The grants are recalculated to the number of enterprises with 20 and more employees in the regions in 2005; these numbers are taken from the Database of MU Regional Development Centre. As Prague could not draw on the innovation program, it is recalculated using the number of such enterprises in the Central Bohemian region. However, with respect to the data compatibility, the indicator is presented for the area of Prague + the Central Bohemian region.

The highest amount of grant from the Innovation Program went to the Pardubice region (200.9 m CZK / 1000 SMEs) and the Hradec Králové region (198.4 m CZK / 1000 SMEs), followed by Prague + the Central Bohemian region (117.3 m CZK / 1000 SMEs). On the other hand, the smallest amount of means was obtained by SMEs in the Plzeň region (29.7 m CZK / 1000 SMEs) and the South Bohemian region (9.9 m CZK / 1000 SMEs). No project was supported in the Karlovy Vary region.

\section{Picture 2: RII - Knowledge Creation (input dimension)}

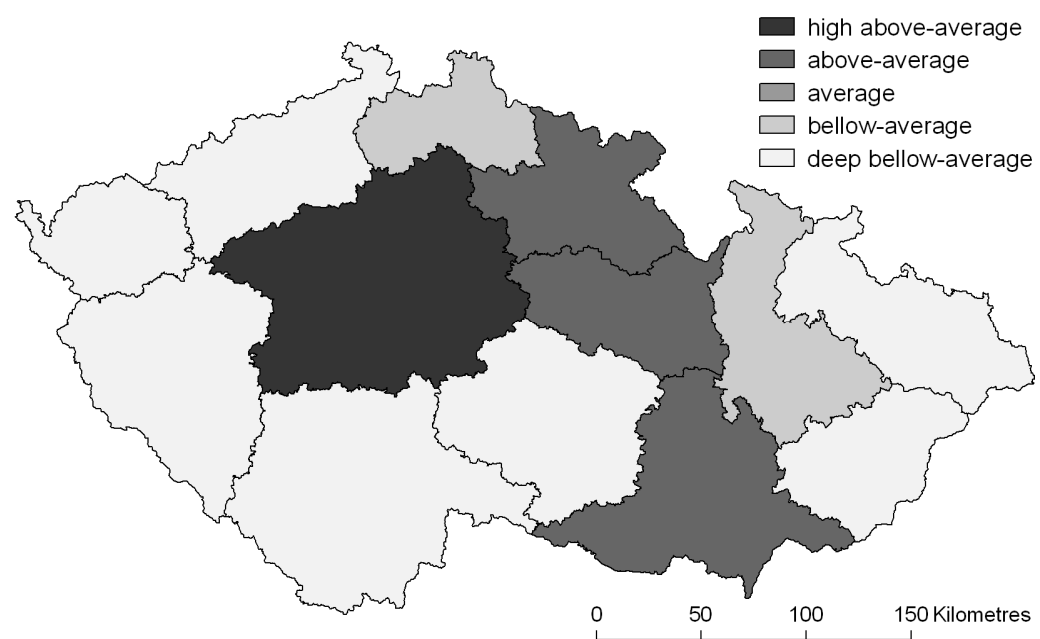

Source: author (data: Czech statistical office, Czechinvest, Regional Development Centre) 


\section{Group 3: Innovation \& Entrepreneurship (input dimension)}

Summary innovation index assesses the following six indicators in this group:

- SMEs innovating in-house (\% of all SMEs),

- innovative SMEs co-operating with others (\% of all SMEs),

- innovation expenditures (\% of total turnover),

- early-stage venture capital (\% of GDP),

- ICT expenditures (\% of GDP),

- SMEs using organisational innovation (\% of all SMEs).

Only 4 indicators were chosen for the construction of the regional innovation index. This group presented the biggest trouble with obtaining the indicators used by SII for the regional level. The data on financing of starting companies by means of venture capital is completely unavailable; on the other hand, this form of financing is hardly used in the CR. Neither the data on innovation expenditures, ICT expenditures, nor organisational innovation are available at regional level. Therefore, alternative indicators were chosen. Finally, the following indicators were included in the Innovation \& Expenditures group:

- the proportion of innovative enterprises in industry (\% of all enterprises),

- the proportion of innovative enterprises in services (\% of all enterprises),

- investments in branches producing ICT in the CR (m CZK / 1 enterprise),

- investments in ICT services branches in the CR (m CZK / 1 enterprise).

\section{The proportion of innovative enterprises in industry}

The proportion of innovative enterprises expresses the number of all production companies that implemented an innovation in the researched period. It can be an innovation of a product, a process, marketing or an organizational innovation. The source of the data is the survey of the Czech Statistical Office called Innovation in the CR in 2005. This survey is a part of European Community Innovation Survey 4 (CIS 4). The data on the proportion of innovative enterprises are not related to 2005 only but to the period of 2003-2005, as it is more suitable to monitor innovations during a longer period of time.

The largest proportion of innovative enterprises in industry can be found in the South Moravian region $(63.7 \%)$, the Pardubice region $(59.5 \%)$ and in Prague + the Central Bohemian region $(59.2 \%)$. The lowest proportion of innovative enterprises in industry is found in the Karlovy Vary region (32.6\%), the Liberec region (42.7\%), the Ústí nad Labem region (45.1\%) and the Plzeň region (45.2\%).

\section{The proportion of innovative enterprises in services}

This indicator is analogical to the previous one but it concerns enterprises providing services. The source of data is also the same.

The largest proportion of innovative enterprises in services is in the Vysočina region $(47.4 \%)$, Prague + the Central Bohemian region $(43.8 \%)$ and the Plzen region $(43.0 \%)$. The lowest proportion of innovative enterprises in industry is found in the Liberec 
region (28.7\%), the Hradec Králové region and the Pardubice region (30.9\% each) and the Ústí nad Labem region (33.6\%).

\section{Investments in branches producing ICT}

Information and communication technologies (ICT) are generally considered to be one of the factors of the economic and social development, mainly because they enable us to cross large geographical distances. The investments in the branches producing ICT in the $\mathrm{CR}$ are expressed as the investment amount in CZK per one enterprise on average. These enterprises are both Czech companies and companies that have branches in the CR. According to the Czech classification CZ-NACE, these are branch 30 Office equipment and computers and branch 32 Radio, television and telecommunication equipment. The data presented here are related to 2005 and they were obtained from the survey of the Czech Statistical Office published in Information Economy in 2008.

The highest investments are achieved by enterprises in the Plzeň region (3.636 m CZK / enterprise) and the Pardubice region and the Zlín region (1.850 m CZK / enterprise each). The enterprises in the Vysočina region (0.084 m CZK / enterprise), the Moravian-Silesian region (0.095 m CZK / enterprise) and the Ústí nad Labem region (0.168 m CZK / enterprise) make investments to the least extent.

\section{Investments in ICT services branches}

Investments in ICT services branches in the $\mathrm{CR}$ are again expressed as the investment amount in CZK per one enterprise on average. These enterprises are both Czech companies and companies that have branches in the CR. According to the Czech classification CZ-NACE, these are branch 72 Services in the computer technology. The data come from the same source as the data for the previous indicator.

The highest investments are achieved by enterprises in the South Moravian region (1.103 m CZK / enterprise), Prague + the Central Bohemian region (0.980 m CZK / enterprise) and the Olomouc region ( $0.633 \mathrm{~m} \mathrm{CZK} \mathrm{/} \mathrm{enterprise).} \mathrm{The} \mathrm{enterprises} \mathrm{in} \mathrm{the}$ Hradec Králové region (0.164 m CZK / enterprise), the Karlovy Vary region $(0.303 \mathrm{~m}$ CZK / enterprise) and the Vysočina region (0,427 m CZK / enterprise) make investments to the least extent. 
Picture 3: RII - Innovation \& Entrepreneurship (input dimension)

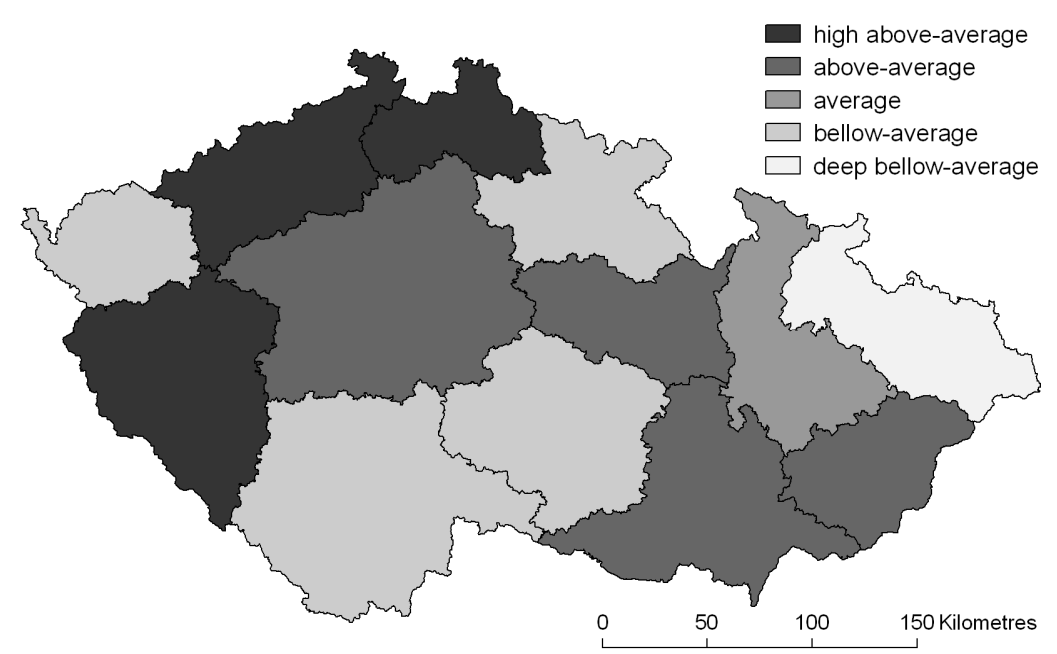

Source: author (data: Czech statistical office)

\section{Group 4: Applications (output dimension)}

Summary innovation index assesses the following five indicators in this group:

- employment in high-tech services (\% of total workforce),

- exports of high technology products as a share of total exports,

- sales of new-to-market products (\% of total turnover),

- sales of new-to-firm products (\% of total turnover),

- employment in medium-high and high-tech manufacturing ( $\%$ of total workforce).

Finding data that would correspond with SII proved to be highly troublesome. First, it was necessary to accept the fact that it is not possible to use the indicators assessing the sales of new products. The authors made the great effort to replace the exports of hightech products indicator with ICT exports. Such indicator seemed to be relevant but using real numbers caused fluctuations of the total regional innovation index because of the total polarization in favour of the Pardubice region. This became a strong reason for excluding this indicator from the study. Therefore, only these two indicators were included in the Applications group in the end:

- employment in high-tech services in the CR (\% of total workforce),

- employment in high-tech manufacturing in the CR (\% of total workforce).

\section{Employment in high-tech services in the CR}

The indicator has been constructed as a percentage of workforce in high-tech services out of total workforce. The data on employment in high-tech fields have been obtained from the Czech Statistical Office publication High-tech Sector. The total workforce in 2005 is based on the selective survey of CSO, the results of which are presented in 
publication Employment and Unemployment in the CR according to Results of the Selective Survey of Workforce of the 4th Quarter of 2005.

The highest percentage of employment in high-tech sector out of total workforce is in Prague + the Central Bohemian region (3.96 \%), the Pardubice region $(3.40 \%)$ and the South Moravian region $(2.90 \%)$. The lowest percentage is in the Liberec region $(0.62$ $\%)$, the Vysočina region $(0.39 \%)$ and the Karlovy Vary region $(0.23 \%)$.

\section{Employment in high-tech manufacturing in the CR}

This indicator was constructed in the same way as the previous one, only the employment in high-tech services was replaced with employment in high-tech manufacturing. The data come from the same sources.

The highest percentage of employment in high-tech manufacturing out of total workforce is in the Pardubice region (3.88 \%), the Hradec Králové region (3.01\%) and the Zlín region $(2.61 \%)$. The lowest percentage is in the Liberec region $(0.80 \%)$, the Ústí nad Labem region $(0.79 \%)$ and the Moravian-Silesian region (0.74\%). An interesting feature of this indicator is the high number (seven) of regions above average and the "bad" position of Prague + the Central Bohemian region (1.76\% - 7th rank).

\section{Picture 4: RII - Applications (output dimension)}

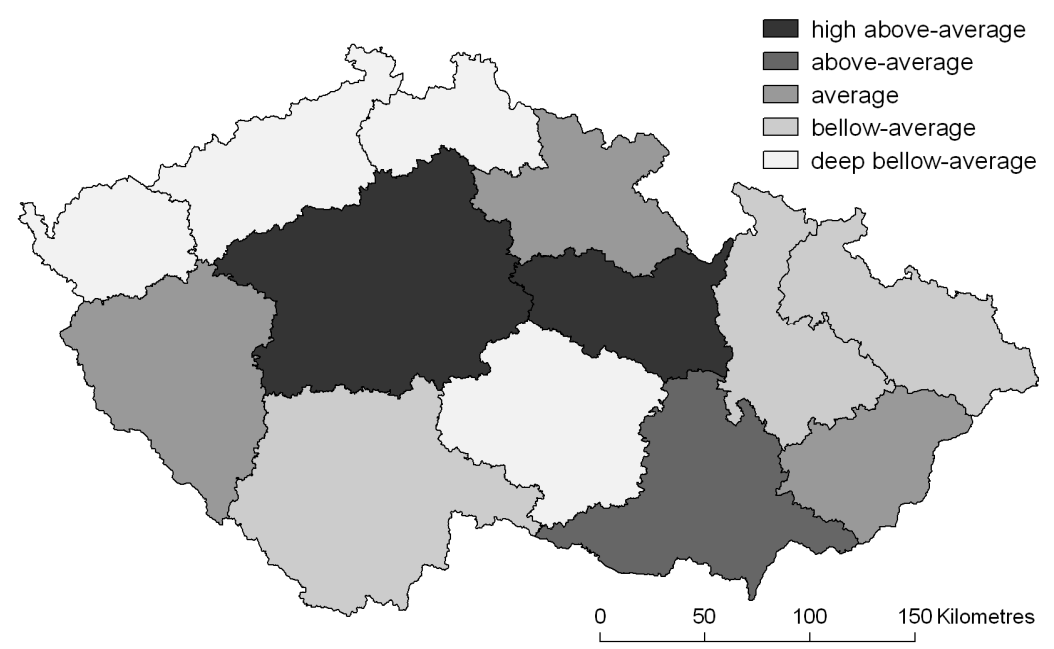

Source: author (data: Czech statistical office)

\section{Group 5: Intellectual Property (output dimension)}

Summary innovation index assesses the following five indicators in this group:

- EPO patents per million population,

- USPTO patents per million population,

- triad patents per million population,

- new community trademarks per million population,

- new community designs per million population. 
Only 2 indicators were chosen for the construction of the regional innovation index. The protection of intellectual property at the international level is not assessed, as this data is not available for NUTS3 regions; moreover, Czech enterprises unfortunately use this protection very seldom. The calculations are based on the data of the Czech Industrial Property Office and concern patents and designs related to 2005. Finally, the following indicators were included in the Intellectual Property group:

- patent applications registered with the Industrial Property Office of the Czech Republic,

- $\quad$ designs registered with the Industrial Property Office of the Czech Republic.

Patent applications registered with the Industrial Property Office of the Czech Republic

Patent applications are expressed as patent applications by authors (inventors) from the $\mathrm{CR}$ registered with the Industrial Property Office of the CR per million inhabitants. We are not assessing the actual granting of a patent but only a registered applications as the granting can take several years and as rather patent applications are surveyed in Europe (in contrast to e.g. the USA).

The largest amount of patent applications per million inhabitants are registered in Prague + the Central Bohemian region (88.6), the Liberec region (70.0) and the South Moravian region (61.0), the smallest amount is on the other hand registered in the Karlovy Vary region (13.1), the Ústí nad Labem region (21.9) and the Vysočina region (27.5). The average of the Czech Republic is 53.6 patents per million inhabitants.

\section{Designs registered with the Industrial Property Office of the Czech Republic}

The registered designs are expressed as designs by authors (inventors) from the CR actually registered with the Industrial Property Office of the CR per million inhabitants. This time we are not assessing the applications but the actual registration of a design, as it only takes several months in contrast to patent granting.

The largest amount of designs per million inhabitants is registered in Prague + the Central Bohemian region (131.1), the Hradec Králové region (116.8) and the Pardubice region (108.8). The smallest amount is registered in the Ústí nad Labem region (46.2), the Plzen region (52.7) and the Olomouc region (73.6). The average of the Czech Republic is 99.7 designs per million inhabitants. 
Picture 5: RII - Intellectual Property (output dimension)

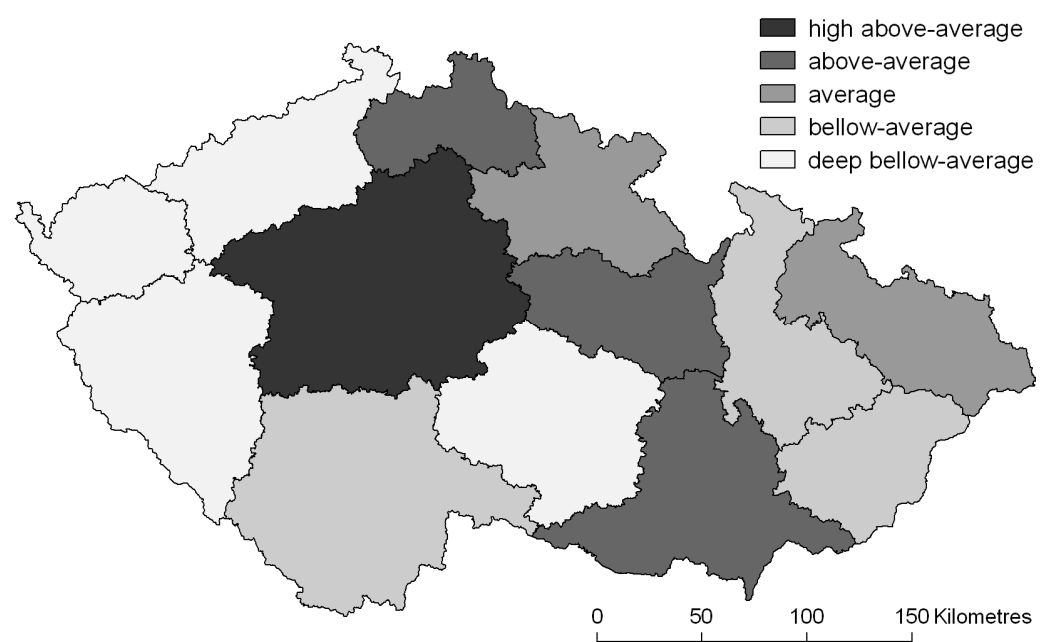

Source: author (data: Czech statistical office)

\section{Regional Innovation Index}

We have presented indicators classified into five groups (groups 1-3 describe the Input Dimension and groups 4-5 describe the Output Dimension) in the previous parts. There are 16 indicators in total. For the construction of the Regional Innovation Index, the input dimension (12 indicators) was included in the calculation with the weight of importance equalling 1 and the output dimension (4 indicators) with the weight of 2 . By increasing the weight of the output dimension, the ratio changes to $3: 2$, which corresponds to the ratio used in SII.

The results of RII were used to create the typology of CR regions, which then divides the regions into those considerably above average, those above average, the average ones, those below average and those considerably below average (see the part "Objectives and Methodology").

The group of regions considerably above average houses only Prague + the Central Bohemian region $(136.5 \%)$. The merging of actually two regions contributed to the reduction of extreme values and to a higher objectiveness of the values of partial indicators. This "region" is considerably above average in all groups except group 3: Innovation and Entrepreneurship, where it is "only" above average.

Regions above average are the Pardubice region (125.8\%) and the South Moravian region $(122.1 \%)$. The Pardubice region is considerably above average in group 4: Applications and average in group 1: Innovation Drivers; it is above average in the other three groups. In contrast, the South Moravian region is above average in all groups except group 1, where it is considerably above average.

Regions Hradec Králové (99.8 \%) and Plzeň (98.7 \%) seem to be average. While the Hradec Králové region ranges between below average and above average in all groups, 
the Plzeň region has a much wider range: it is considerably above average in group 3, and considerably below average in two groups -2 and 5 .

The highest number of regions (five in total) is below average: the Zlín region (88.6\%), the Olomouc region (80.6\%), the Moravian-Silesian region (76.5\%), the Liberec region $(74.3 \%)$ and the South Bohemian region $(72.9 \%)$. These regions do not achieve much good assessment in individual groups, the only exception being the Liberec region, which is considerably above average in group 3 .

The remaining three regions are considerably below average. The Vysočina region (58.1 $\%$ ), the Ústí nad Labem region (57.2\%) and the Karlovy Vary region (44.8\%) fall considerably below average in four out of the five groups. Their innovation potential is obviously very weak; therefore, it is not surprising that also their summary assessment is bad.

Picture 6: Regional Innovation Index

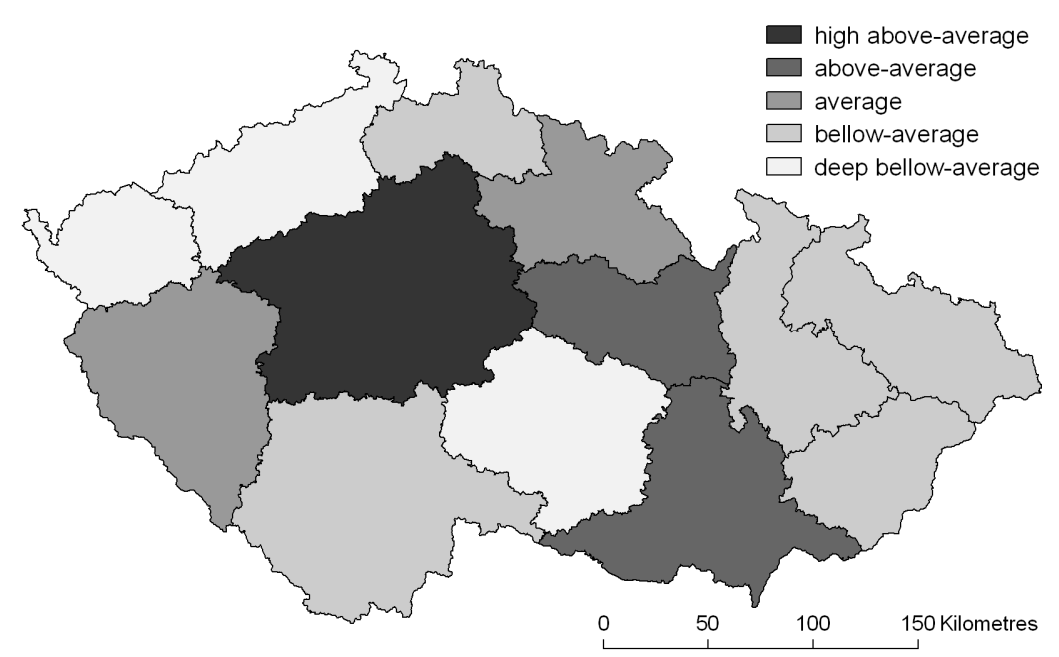

Source: author

\section{Status and dynamics of regional competitiveness indicators development}

In the previous part we specified a typology of Czech regions by means of regional SII using the detailed methodology based on the Oslo Manual. Now we are going to briefly present a study carried out in July $2006^{1}$ which only uses five indicators, giving each of them a different specific weight of importance. The indicators are: regional GDP per capita in constant prices, average gross monthly income, unemployment rate, educational attainment index and migration balance.

1 Žítek, Kunc, Tonev (2006)

164 
The study aimed to use the synthesis of the indicators to compare regions with each other, both from the point of view of absolute indicator values and from the point of view of their changes occurring in the researched period of 1995-2004. The main objective was to produce a developmental typology of regions of the Czech Republic, its result being the classification of the regions into the regions over average, average regions, regions below average and regions considerably below average.

\section{Regional GDP}

GDP is the total value of all goods and services produced in an economy during a specific time period. The calculation of the regional GDP in the CR was based on scheduling of national account indicator values into regions in dependence on the indicators, 'keys', found in the regions (the 'top-down' method). The field structure of the gross added value was scheduled into regions and districts in dependence on the volume of wages found out in individual workplaces. From the very beginnings of GDP regionalization, the Czech Statistical Office presumed that it would change to the more precise 'bottom-up' method but to use this method it first had to provide suitable conditions. Thanks to the understanding of mainly production companies, the Office was able to obtain the data necessary for the regionalization of the gross added value and in this way also of GDP for the sector of non-financial institutions (especially production and service providing companies).

The highest values of the regional GDP in 2004 were achieved in Prague and the Central Bohemian region with more than 256,000 CZK per capita, followed by the Plzen region $(162,000 \mathrm{CZK})$ and the South Moravian region $(161,700 \mathrm{CZK})$. The lowest GDP per capita is in the Karlovy Vary region $(136,800$ CZK) and in the Olomouc region $(136,900 \mathrm{CZK})$.

In the period of 1995-2004 the constant-price regional GDP increased the most in Prague and the Central Bohemian region - by $35.5 \%$, then in the Hradec Králové region and in the Vysočina region by $22.1 \%$ and in the South Moravian region by $21.0 \%$. On the other hand, the lowest growth of regional GDP was in the Karlovy Vary region by $2.0 \%$ and in the Ústí nad Labem region by $3.1 \%$.

The growth of GDP per capita between 1995 and 2004 was the highest in Prague and the Central Bohemian region $36.4 \%$, and with some distance the Hradec Králové region $23.7 \%$, the Vysočina region $23.5 \%$ and the South Moravian region $23.1 \%$ follow. The lowest growth can be seen in the Karlovy Vary region $2.5 \%$ and the Ústí nad Labem region $3.7 \%$. The other regions range between $12.5 \%$ and $20.0 \%$.

\section{Average Income}

At the beginning of the 1990s, the average monthly income in the Czech Republic was at the level of 3,200 CZK. There were no considerable differences in the average income among individual regions; the differences were a matter of hundreds. The market mechanisms had only started to be created and the average monthly incomes in the first years of the reform were still connected with the economic mechanisms of the central planning.

Real wages grew relatively evenly in the period of 1995-2000 - by 700-1,200 CZK every year in dependence on the economic performance of individual regions. The 
exception was Prague and the Central Bohemian region, where incomes grew faster. 2001 became a 'troublesome' year for the continuity of the real wages value development, as the Czech statistics ceased including average wages in regions using the 'workplace' method and started to use a less correct and worse comparable company method. It means that the average monthly incomes of employees were included in regions in dependence on the company headquarters, not the real workplace as before. The statistical consequence was that the growth of average incomes jumped down in all regions (growth by only 400-700 CZK).

In the following years, the average monthly incomes increased again with a higher speed, in 2004 this indicator stopped at the value slightly above 18,000 CZK for the Czech Republic. The highest values and the highest growth dynamics are to be found in Prague and the Central Bohemian region $(21,400 \mathrm{CZK})$, followed by the MoravianSilesian region $(16,900 \mathrm{CZK})$ and the Plzen region $(16,800 \mathrm{CZK})$. It means that none of the regions reached the average of the Czech Republic and the value of average gross monthly income in the entire CZ is strongly affected by the Capital City of Prague. The lowest values of average incomes are to be found in the Karlovy Vary region and in the Olomouc region $(15,400 \mathrm{CZK})$.

The index of the development of average gross monthly incomes in 1995-2004, when $1995=100 \%$, is again the highest for Prague and the Central Bohemian region (224.4 $\%)$, for the Liberec region (214.6\%) and the Vysočina region (214.0\%). The lowest long-term growth of average monthly incomes was found in the Karlovy Vary region (196.7\%) and both of the most structurally affected regions - the Ústí nad Labem region (201.2\%) and the Moravian-Silesian region (202.4\%).

\section{Unemployment}

Until the end of November 1989, there was no officially accepted unemployment in the Czech Republic; unemployment was considered 'parasitism' and it was prosecuted. At the end of 1989, there were several hundreds of unemployed persons registered.

After the number of unemployed people dramatically increased during the first years of the economic reform and the unemployment rate of the CR reached $4.1 \%$ (i.e. 221,700 of the unemployed) in 1991, the situation became relatively stable around the mid1990 s, the number of the unemployed being between 130,000 and 200,000 and the unemployment rate being around 3-4\%. This situation was to a great extent created artificially, as it was influenced by the CR government fiscal policy.

The highest relative unemployment rate increase in the period of 1995-2004 (CR $2004 / 1995=100 \%$ ) was determined in the Olomouc region (by $125.4 \%$ ), followed by the Moravian-Silesian region and the South Moravian region (both over $120 \%$ ). The limit of $100 \%$, it means the CR average, was also exceeded by the Karlovy Vary region, the South Bohemian region and the Hradec Králové region. On the other side of this scale, there are Prague and the Central Bohemian region (index 71.1\%) and also the Liberec region, the Plzeň region and the Zlín region (all of them below $90 \%$ ).

In 1995, the unemployment rate in the CR achieved the level of $4 \%$ and the regions with most troubles, those most affected by the restructuring of their one-field oriented economic base - the Ústí nad Labem region and the Moravian-Silesian region (unemployment rates of $7.1 \%$ and $5.8 \%$ respectively) had already been profiled. Four 
regions were above the $\mathrm{CR}$ average. The best position was held by the South Bohemian region $(2.5 \%)$, the Hradec Králové region and Prague and the Central Bohemian region (both $3.1 \%$ ).

A significant milestone in the CR unemployment development came about in 1998 and 1999, when the economic recession reached its peak and the unemployment rate jumped up (4.8 \% in 1997, $8.7 \%$ in 1999). Again, the Ústí nad Labem region (15.4\%) and the Moravian-Silesian region (13.0\%) were at the worst positions among the CR regions in 1999; the limit of $10 \%$ was exceeded by the Olomouc region as well (10.6\%). These were the three regions above the CR average. And yet again, the best position was held by the South Bohemian region and by Prague and the Central Bohemian region (both $5.8 \%$ ).

In the following years, the unemployment rate fluctuated - it decreased until 2002 and it started to increase slightly again in the following year. However, there were no more considerable fluctuations or jumps. At the end of 2004, the unemployment rate in the $\mathrm{CR}$ was $8.3 \%$ and besides the 'traditionally above average' regions (the Ústí nad Labem region, the Moravian-Silesian region both $14.5 \%$, the Olomouc region $12.0 \%$ ) also the Karlovy Vary region $(9.4 \%)$ and at the same level the South Moravian region appeared above average. Prague and the Central Bohemian region (4.6\%), followed by the South Bohemian region $(5.7 \%)$ and the Plzen region $(5.8 \%)$ were at the best position since 2001 .

\section{Educational Attainment of the Population}

The educational attainment of the population is one of the important socio-economic indicators that contribute in positive or negative terms to the regional competitiveness.

In 1991, the proportion of college and university graduates in the total number of inhabitants older than 15 was $7.2 \%$, which was very little vis-à-vis economically developed countries. The highest educational attainment levels were achieved in the regions where the most significant municipality has been a centre of higher (mainly tertiary but also secondary) education, i.e. Prague and the Central Bohemian region (10.9\%), the South Moravian region (8.4\%) - the only regions above the CR average and then with some distance the Olomouc region, the South Bohemian region and the Plzeñ region (all of them $6.3 \%$ ). The other end of the scale was occupied by the Ústí nad Labem region (4.3\%) and the Karlovy Vary region $(4.7 \%)$.

At the end of 2004, the selective workforce survey showed that nearly a tenth of the population (9.9\%) of the Czech Republic older than 15 had attained tertiary education and more than two fifths $(40.8 \%)$ had graduated from at least secondary education institutions. Again, especially Prague and the Central Bohemian region (tertiary education $15.2 \%$, tertiary + secondary $50.5 \%$ ) surpassed the average of the entire CR but also the South Moravian region $(12.5 \%, 42.3 \%$ respectively) exceeded the average. The Ústí nad Labem region had a three times lower proportion of college or university graduates than Prague and the Central Bohemian region (5.1\%), the Liberec region and the Karlovy Vary region also presented very low figures. Similarly, these regions were at last positions as far as the proportion of secondary and upper education graduates is concerned, however, the proportion difference from Prague and the Central Bohemian region was not as wide as in the case of tertiary education graduates. 
Educational attainment index is an interesting indicator which shows the advantages or deficiencies of the above mentioned regions as far as education is concerned. The index is "a proportion of the secondary education graduates (the allotted weight of importance being 1) and college or university graduates (weight 3 ) in the total number of population aged 15 and over." Prague and the Central Bohemian region are in the lead (index of 81 $\%$ ), followed by the South Moravian region (67.4\%). These two regions are above the CR average $(60.7 \%)$. The index attains very low values in the Ústí nad Labem region, the Karlovy Vary region and the Liberec region (index below $50 \%$ ).

The relative increase of the educational attainment index during the period of 19952004 shows considerably higher values in the five 'Moravian' regions (i.e. the Vysočina region as well) - in all of them, it was more than 10 percentage points. In 'Bohemian regions,' only Prague and the Central Bohemian region (13.6 percentage points) and the Plzeň region (10.8) achieved similar values. In the other regions, the interval width was much lower (5.3-8.4 percentage points). This space dimension also appears in the analysis of the increase of the proportion of tertiary education graduates and of secondary and upper education graduates during the researched years.

\section{Migration Balance}

Migration is one of the basic processes affecting the distribution and structure of the population in the territory. The attention was only paid to the internal migration (defined as a change of the address from a municipality to another within the territory of the $\mathrm{CR}^{1}$ ).

For the whole period of the 1990s, the balance of most regions rather oscillated around zero without any traceable trend, and the population increases were alternated with decreases. Only the Karlovy Vary region and the Moravian-Silesian region and to a lesser extent the Vysočina region clearly and obviously suffered losses during the 1990s. On the other hand, the South Bohemian region and the Plzen region and also the "Prague" region (in the first years mainly thanks to Prague, then also thanks to the Central Bohemian region) regularly gained from the population's migration.

Only in the other part of the researched period (about from 2001), probably thanks to the growing regional differences, even the remaining regions started to be more obviously profiled as emigration or immigration areas. Besides Prague and the Central Bohemian region, only the Plzeň region and the South Bohemian region increased in population, the Pardubice region had an even balance of the emigrated and the immigrated. All the other regions decreased in population.

\section{Development typology of regions}

The total assessment of the competitiveness of Czech regions took into consideration the five components analysed in Žítek, Kunc, Tonev (2006), i.e. GDP, average income, unemployment (or unemployment rate), educational attainment (or educational attainment index) and migration (or migration balance).

\footnotetext{
${ }^{1}$ In the territory of Prague, it is also from an urban district to another but this data has not been included.
} 
For the purpose of the calculation for 2004 (the stable state), the absolute values of the components for individual regions were expressed in per cents, where the base (it means $100 \%$ ) was the value (the average) of the entire CR. For the unemployment, the resulting values were inverted so that the regions with an unemployment rate lower than the CR average had a value higher than $100 \%$. For the migration balance, where the republic sum of the internal migration is logically zero and whose values can also be negative, the values were added to an auxiliary value of 100.0. To determine the total score, individual components were allotted the following weights of importance (GDP 0.4 ; incomes 0.05 ; unemployment -0.2 ; education -0.3 and migration -0.05 ); these correspond, as the authors presume, to the importance of the selected indicators for the assessment of the competitiveness of CR regions.

The procedure was analogical for the period of 1995-2004 (dynamic development): the change of each indicator between 1995 and 2004 for the entire CR was taken as the base for the calculation of values of individual regions. Again, migration balance was an exception - the average of the last three researched years was used to find out the trend and its value was added to 100.0. To determine the total score the above-mentioned weights of importance were again allotted to the individual components.

Using the results, the regions of the $\mathrm{CR}$ were divided into four categories for both the stable state of 2004 and the dynamic development in 1995-2004.

\section{Picture 7: Competitiveness level of CR regions}

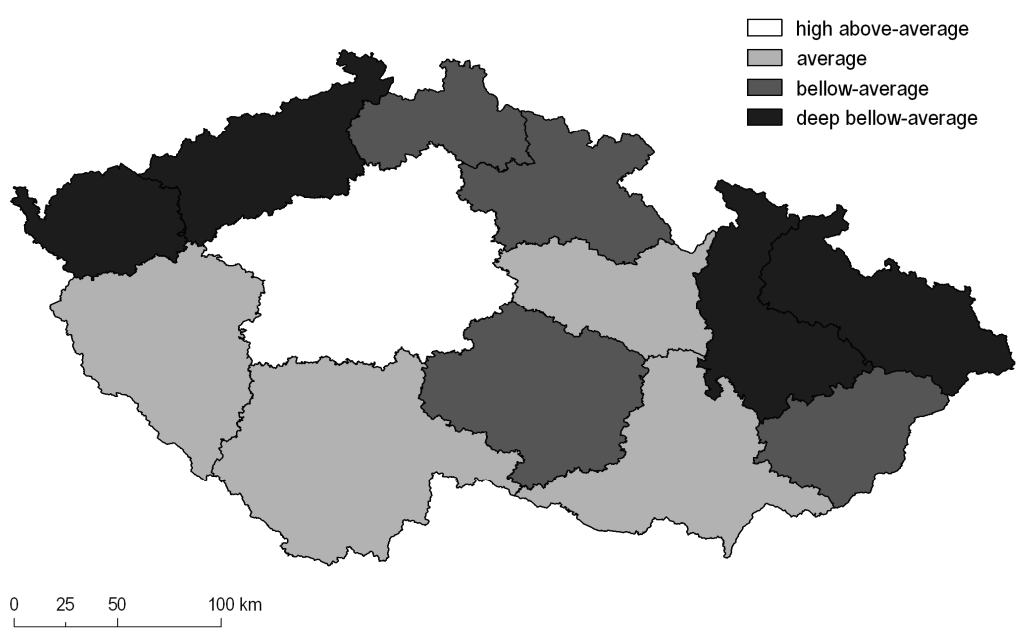

Source: Žitek, Kunc, Tonev (2006)

The resulting typology of CR regions based on the assessment of their competitiveness is presented in the following table. It is a combination of the stable state of 2004 and the dynamic development of 1995-2004. The regions of the CR were provided with a verbal assessment of competitiveness similar to assessments of the "state" and "dynamics" separated. 
Only the position of Prague and the Central Bohemian region was assessed as considerably over average in both cases (the stable state and the dynamic development). The average position in the competitiveness assessment was in both cases granted to the Pardubice region, the Plzeň region and the South Moravian region, static values of 2004 also included the South Bohemian region in this group but the long-term development of 1995-2004 puts it in the category below average. The Hradec Králové region and the Vysočina region had, in contrast to the South Bohemian region, a better position in the dynamic development (average assessment) but worse in the state analysis of 2004 (below average).

The position below average belonged, for both the state and the dynamic development, to the Liberec region and the Zlín region; the assessment of the development put also the Moravian-Silesian region and the Olomouc region in this category. On the other hand, these two regions showed only little competitiveness in the state analysis of 2004 and they fell into the category considerably below average.

The worst position in the interregional competitiveness was occupied, on the basis of the assessment of partial components and the consequent total score (the state and the dynamic development), by the Karlovy Vary region and the Ústí nad Labem region and their assessment could not be other than considerably below average.

Table 1: Typology of CR regions

\begin{tabular}{|c|c|c|c|c|}
\hline \multirow[b]{2}{*}{ Status in 2004} & \multicolumn{4}{|c|}{ Dynamics in the period of $1995-2004$} \\
\hline & $\begin{array}{l}\text { Considerably } \\
\text { above } \\
\text { average }\end{array}$ & Average & $\begin{array}{l}\text { Below } \\
\text { average }\end{array}$ & $\begin{array}{c}\text { Considerably } \\
\text { below } \\
\text { average }\end{array}$ \\
\hline $\begin{array}{c}\text { Considerably above } \\
\text { average }\end{array}$ & $\mathrm{PR}+\mathrm{CB}$ & & & \\
\hline Average & & SM, PL, PU & SB & \\
\hline Below average & & HK, VY & LB, ZL & \\
\hline $\begin{array}{c}\text { Considerably below } \\
\text { average }\end{array}$ & & & MS, OL & $\mathrm{KV}, \mathrm{UL}$ \\
\hline
\end{tabular}

Source: Žitek, Kunc, Tonev (2006)

\section{Conclusion}

The study comes with a methodical input on the assessment of the regions' innovation potential within the national economy. The construction of the Regional Innovation enables us to compare the CR regions with each other and to classify them into groups, in this way creating their typology. We were able to select 16 indicators (12 input dimensions, 4 output dimensions) which more or less resemble the inspired model of SII. The results have been interpreted at the end of the first part of the text and then, a study carried out by Žítek, Kunc, Tonev in 2006 was presented. This study had the same objective (to create the typology of CR regions) but it was based on completely different assumptions and methodology.

Having summarized the results of both the studies, we can draw the following comparative table: 
Table 2: Typology of $\mathrm{CR}$ regions

\begin{tabular}{|c|c|c|}
\hline & RII & Žítek, Kunc, Tonev (2006) \\
\hline Considerably above average & PR+CB & PR+CB \\
\hline Above average & PU, SM & \\
\hline Average & HK, PL & SM, PL, PU, SB \\
\hline Below average & ZL, OL, MS, LB, SB & HK, VY, LB, ZL \\
\hline Considerably below average & VY, UL, KV & MS, OL, KV, UL \\
\hline
\end{tabular}

Both of the studies confirm an exceptional position of Prague + the Central Bohemian region. About the other regions we can say that either both of the studies agree on their group classification or they put them a group higher or lower. This fact confirms the primary assumption that the methodological foundations of both studies were chosen suitably. the assertion that the indicators for the construction of RII were suitably created and used, both with respect to individual indicators and with respect to the construction of RII as a whole could be another relevant conclusion.

In possible future research, it is necessary to focus attention on making the indicators more precise, or on suitable additions to their structure, mainly as far as the innovation output dimension is concerned. The presented study has limitations not discussed so far as the considerable part of the input data come from selective surveys of national statistics represented by the Czech Statistical Office in the CR. Should RII be used for international comparisons of regions, which is highly important and necessary for the innovation field, the input data and the consequent indicators have to be constructed so that their international compatibility is ensured, even though it might mean that the assessment would move from the NUTS3 level to the NUTS2 level. This fact will also be a subject of further research. 


\section{References}

CZECHINVEST (2008). Statistika čerpání dotací a zvýhodněných úvěrů z programů OPPP. Retrieved from http://isop.czechinvest.org/isop_oppp/WebVystupy/

stat_cerp_dotaci_z_OPPP.aspx

ČSÚ: High-tech sektor v období 1995-2006, Retrieved from http://www.czso.cz/ csu/redakce.nsf/i/high_tech_sektor

ČSÚ: Inovace v ČR v roce 2005 (kód 9605-06)

ČSÚ: Informační ekonomie v číslech 2008, Retrieved from http://www.czso.cz/csu/ redakce.nsf/i/informacni_ekonomie_v_cislech_2008

ČSÚ: Krajská ročenka Jihomoravského kraje 2006 (kód 13-6201-06)

ČSÚ: Ochrana průmyslového vlastnictví v ČR v letech 2001-2005 (kód 9612-06)

ČSÚ: Regionální účty 2005 (kód 1371-06)

ČSÚ: Trh práce 1993 - 2006 (kód 3103-07)

ČSÚ: Ukazatele výzkumu a vývoje za rok 2006 (kód 9601-07)

ČSÚ: Výsledky ad hoc modulu 2003 o celoživotním vzdělávání za rok 2003 (kód 311904)

ČSÚ: Využívání informačních a komunikačních technologií v domácnostech a mezi jednotlivci v roce 2007 (kód 9701-07)

ČSÚ: Zaměstnanost a nezaměstnanost v ČR podle výsledků výběrového šetření pracovních sil za 4. čtvrtletí 2005 (kód 3101-05)

ČSÚ (Czech Statistical Office): www.czso.cz

Database of Masaryk University Regional Development Centre (2006)

HUKALOVÁ, M. (2005). Statistika inovací. Inovační podnikání a transfer technologií. AIP ČR. 2005 , č. 4/2005, s. 5-6. Praha.. ISSN 1210-4612.

KLÍMOVÁ, V. (2006). Inovační procesy. Brno: Masarykova univerzita. $180 \mathrm{~s}$. ISBN 80-210-4166-8

OECD: OSLO MANUAL. Guidelines for collecting and interpreting innovation data. Third edition. 2005.

PRO INNO EUROPE: www.proinno-europe.eu

TONEV, P. (2007). Institucionální báze výzkumu a vývoje a inovačně nosných oborů vysokého školství. In Faktory konkurenceschopnosti (komparace zemí V-4). Brno: Centrum výzkumu konkurenční schopnosti České ekonomiky. s. 236-243. ISBN 97880-210-4455-5

ŽÍTEK, V., KLÍMOVÁ, V. (2006). Assessment of Public Programmes Co-Financed from Structural Funds of EU for Support of Innovative Enterprise. In 4th International Conference for Young Researchers of Economics. Gödöllö: Szent István University. s. 331-338. ISBN 963-9483-67-2. 
ŽÍTEK, V., KUNC, J., TONEV, P. (2006). Vybrané indikátory regionální konkurenceschopnosti a jejich vývoj. Working papers. Brno: Centrum výzkumu konkurenční schopnosti České ekonomiky, 21, 36 s. ISSN 1801-4496.

\title{
INNOVATION PERFORMANCE OF THE CZECH REGIONS
}

\section{Vladimír Žítek}

Masaryk University, Faculty of Economics and Administration, Lipová 41a, 60200 Brno, Czech Republic, e-mail: zitek@econ.muni.cz, phone: +420549494627

\begin{abstract}
Innovations play the key role in the today's globalized world economy. This is a fact which also the European Union is aware of. Therefore, it is concerned with the innovation support. And individual national economies focus on the characteristics that influence their innovation potential. Several various methods are used for the evaluation of the innovation efficiency, for example the Summary Innovation Index (SII), by the means of which the individual countries are assessed through 25 indicators. This contribution aims to find out which of the indicators involved in the method are available, so that this method could be used for the evaluation of the innovation efficiency of the individual regions at the level of NUTS3. For this purpose, the Regional Innovation Index (RII) has been defined and it uses 16 indicators, the same as or similar to the original methodology, to compare the regions of the Czech Republic. RII maintains the original weight ratio of innovation input and output dimensions. RII is used as a base for the creation of regional typology, which divides the regions into those considerably above average, those above average, the average ones, those below average and those considerably below average. Moreover, the results are compared with the conclusions of another study, which used a simpler methodology. This makes us able to draw final conclusions and also to define bases for further research.
\end{abstract}

Key words: Regional development, Innovation index, evaluation, typology of regions

JEL Classification: R120, O180

DOI: $10.2478 / \mathrm{v} 10135-011-0003-1$ 